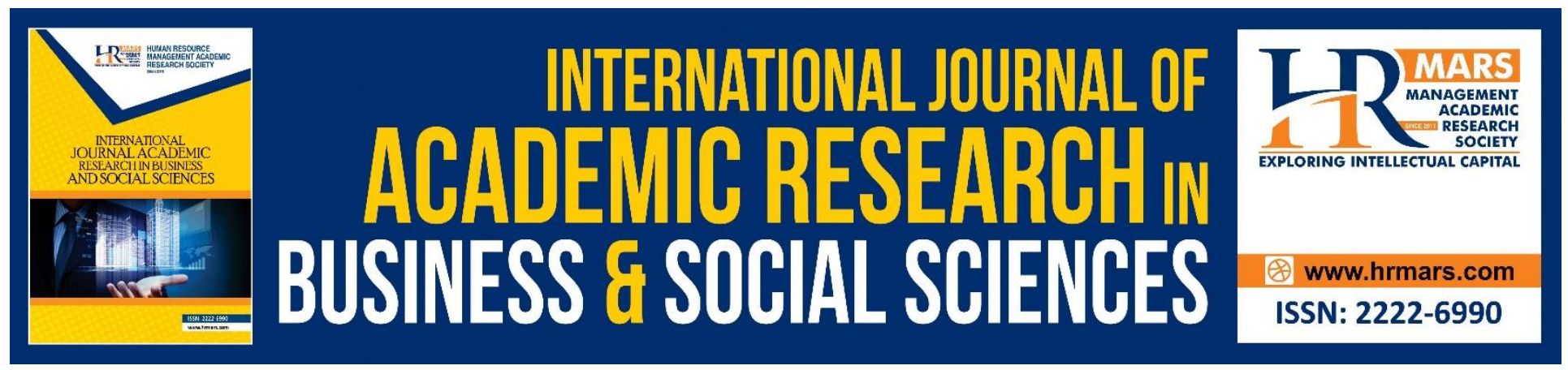

\title{
The Impacts of Academic Self-Efficacy on Academic Outcomes: The Mediating effect of Student Engagement
}

\author{
Shama Noreen, Ali Hasan, Iqra Batool, Awais Ali
}

To Link this Article: http://dx.doi.org/10.6007/IJARBSS/v8-i11/4904

DOI: $10.6007 /$ IJARBSS/v8-i11/4904

Received: 07 Oct 2018, Revised: 26 Oct 2018, Accepted: 24 Nov 2018

Published Online: 26 Nov 2018

In-Text Citation: (Noreen, Hasan, Batool, \& Ali, 2018)

To Cite this Article: Noreen, S., Hasan, A., Batool, I., \& Ali, A. (2018). The Impacts of Academic Self-Efficacy on Academic Outcomes: The Mediating effect of Student Engagement. International Journal of Academic Research in Business and Social Sciences, 8(11), 315-327.

Copyright: (C) 2018 The Author(s)

Published by Human Resource Management Academic Research Society (www.hrmars.com)

This article is published under the Creative Commons Attribution (CC BY 4.0) license. Anyone may reproduce, distribute, translate and create derivative works of this article (for both commercial and non-commercial purposes), subject to full attribution to the original publication and authors. The full terms of this license may be seen

at: http://creativecommons.org/licences/by/4.0/legalcode

Vol. 8, No. 11, 2018, Pg. 315 - 327

http://hrmars.com/index.php/pages/detail/IJARBSS

JOURNAL HOMEPAGE

Full Terms \& Conditions of access and use can be found at http://hrmars.com/index.php/pages/detail/publication-ethics 


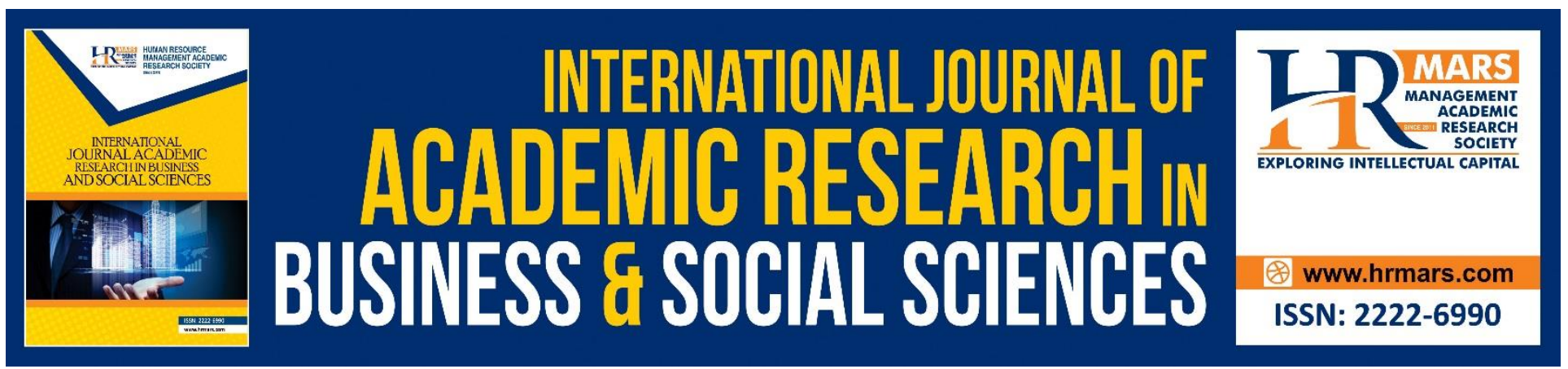

\title{
The Impacts of Academic Self-Efficacy on Academic Outcomes: The Mediating effect of Student Engagement
}

\author{
Shama Noreen, Ali Hasan, Iqra Batool, Awais Ali \\ Department of Management and Administrative Sciences, University of Narowal
}

\begin{abstract}
Examines the influence of ASE on student engagement and academic outcome and detect if student engagement as a whole mediates the relationship between ASE and academic outcome. Survey is conducted in a university; students are the subjects, sample of 169 is taken. The scales belong to the past studies and are reliable. Multiple regression analysis was used to check the mediation and for testing hypothesis. Results shows that ASE influences both student engagement and academic outcome positively and significantly and student engagement influences academic outcome positively and significantly too. It means ASE influences academic outcomes directly as well as indirectly through student engagement. This study also has some limitations. Student engagement was taken as a whole concept; its sub parts are not considered in this study. This type of study has not been done in this area so research was lacking and the gap was still existed.
\end{abstract}

Keywords: Self-Efficacy, Academic Outcomes, Student Engagement, Mediation

\section{Introduction}

There have been many studies which explains the phenomenon of drop out and there are different reasons to drop out such as differences within schools, communities and student's behavior and even in students. Dropout means departure from the institution without finishing the education and getting no certificate at the end (Goel, 2004). Students leave the institution at any stage, early, middle or last. Pakistan's education system comprises of 5 stages and there is high dropout in all 5 stages (Sabir, 2009). The phenomenon is not only prevailing in Pakistan but it has increased in developed countries too. In recent years' students' dropout from higher education has become a problem for UK (Lockhart, 2004). 1.2 million students have drop out from high school in united states annually (Bill and Melinda Gates Foundation, 2014). Student's admission point, former school background, academic performance of undergraduate students (Martha, 2009) parents' education and students' motivation are the factors of institutional accomplishment (Farooq, 1994). How to enhance academic performance, achievements and standards are the concerns for institutions, parents, teachers, and 
INTERNATIONAL JOURNAL OF ACADEMIC RESEARCH IN BUSINESS AND SOCIAL SCIENCES Vol. 8, No. 11, Nov, 2018, E-ISSN: 2222-6990 @ 2018 HRMARS

society at large. is one of the biggest concern. They all emphasize, because scientific and technological development, political advancement and success in life does not seem possible without educational attainment. According to Brown and Lent (2006) educational and occupational performance is strongly related with academic performance. There are many factors affecting academic performance, achievements, ability and intelligence of students, such test anxiety (Yıldırım \& Ergene, 2003), socio-economic factors (Lillydahl, 1990), peer relationships (Bjarnason, 2000), motivation (Bergin, 1992). Student engagement is also the determinant of academic outcomes, there is a strong relationship between students' academic achievements and engagement. Class room setting are being changed from traditional to blended or electronically for the better engagement of students. But still there are a bit of students who put effort to engage in class discussion (Weaver \& Qi, 2005). Previous studies explain why students do not participate, they may have lack of confidence, and they feel inadequacy in front of others, criticism on their abilities, Fear of disapproval (Weaver \& Qi, 2005).

According to previous study students' engagement and academic self-efficacy was positively related with positive academic outcomes (Galyon, Blondin, Yaw, Nalls, \& Williams, 2012). Self-efficacy was one of the strongest predictor of academic performance among cognitive factors (Sheu et al., 2010). Self-efficacy refers to beliefs about having ability or capabilities to produce results by actions (Bandura, 2006). Academic self-efficacy is a more detailed aspect of self-efficacy which reflects a student's perceived competence in academic field. Students who are willing to take steps, about their academic career, have more believe in their academic capabilities (Brown, Lent, \& Larkin, 1989). The purposes of this study is to (1) explore the impact of academic self-efficacy on student's engagement and academic outcomes; (2) verify the impact of student engagement on academic outcomes; (3) explore the mediating effect of student's engagement between academic self-efficacy and academic outcomes.

\section{Literature Review}

The relationship among Academic self-efficacy, student engagement and Academic performance Self-efficacy is a concept and chunk of the larger hypothetical framework called social cognitive theory proposed by Bandura (1986) which placed that there are three elements, which predicts the human working and activities, to be specific, the person, their behavior, and their environment. These components apply proportional effects on one another. Self-efficacy is concerned about a man's faith in his or her capacities to learn or perform necessary tasks to achieve goals at assigned levels (Bandura \& Wessels, 1997). A lot of researches done by Bandura on self-efficacy have demonstrated that students' view of their capacities to play out an engagement incredibly impacts their success.

Self-efficacy influences academic motivation, learning and achievement (Brown et al., 1989). In a meta-investigation, it was affirmed that academic self-efficacy had an impact on academic achievement and engagement, done by (Bandura, 1989; Multon, Brown, \& Lent, 1991). Academic self-efficacy alludes to people can utilize their capacities to finish the study, control their own practices, and judge their academic accomplishment. Academic self-efficacy was the most grounded single indicator of students' academic accomplishment and performance. Rather than a general selfefficacy measure, academic particular activities was a better measure of academic self-efficacy (Wood \& Locke, 1987). In Comprehensive Meta-analysis it was found that the outcomes demonstrate 
that academic self-efficacy and student engagement yielded a noteworthy average impact estimate and that they were related. As per past investigation students' engagement and academic selfefficacy was decidedly related with positive academic results (Bresó, Schaufeli, \& Salanova, 2011). Based on above discussion, hypothesis 1 is as follows.

H.1 Academic self-efficacy positively related with student engagement.

In many previous study it was found that academic self-efficacy had a strong and positive relation with academic achievements. According to (Adeyemo, 2007) ASE was significantly correlated with academic performance and ASE positively and significantly influenced academic performance. In a cross sectional study (Afari, Ward, \& Khine, 2012) found that high ASE was associated with Academic performance. ASE positively correlated with performance (Coutinho \& Neuman, 2008). De Clercq, Galand, Dupont, and Frenay (2013) found that ASE predict achievement and performance in PE and science class respectively. Those who have high levels of ASE tended to show higher adaptation of mastery goals than lower ASE (Hsieh, Sullivan, \& Guerra, 2007), GPA was positively and directly related to ASE (Feldman \& Kubota, 2015; Hsieh et al., 2007). Based on above discussion hypothesis 2 is as follows.

H.2 Academic self-efficacy positive and significantly related with academic outcomes

The relationship between student engagement and Academic performance Feeling and sense making as well as being dynamic are required for Engagement (Harper \& Quaye, 2009). It was thought as a multi-dimensional concept, in the previous decade (Günüç \& Kuzu, 2014). Hu furthermore, (Kuh, 2001) and (Kuh, 2009) allude to Student Engagement as the time distributed by students to instructive exercises to add to the coveted results and as the nature of their linked endeavors. (Krause \& Coates, 2008) related Student Engagement with the high caliber in learning results. Student Engagement is contained four distinct components: abilities, emotional, participation/association, and performance (Handelsman, Briggs, Sullivan, \& Towler, 2005). The skill engagement factor centers intensely around

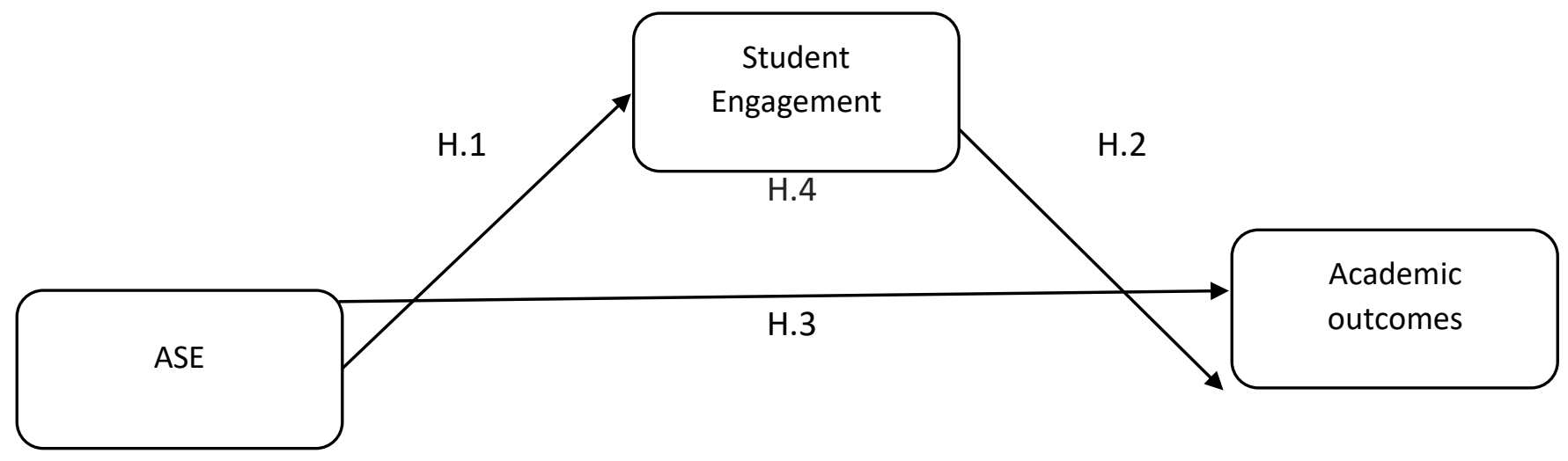

Fig.1 
understudies honing their aptitudes, for example, taking notes, participation, and finishing tasks. The emotional engagement factor comprises of natural association in classes like want to take in the material, applying the material to life, and discovering approaches to make the class all the more fascinating. The participation/association factor looks at conduct engagement with the material like bringing your hand up in class, making inquiries, and taking part in class exchanges. The performance engagement factor centers around outward inspiration like getting decent evaluations and doing great on tests. In this manner, these elements appear to identify with ASE since they have a tendency to mirror the engagement capacity of the students to their separate courses.

Gurung, Daniel, and Landrum (2012) found that students' utilization of skill engagement for example, taking notes, perusing the content, and utilizing educational guides to test learning associated decidedly with their test execution. Research by Daniels et al. (2009) uncovered, student's engagement are identified with better results. Studies demonstrate that if students are arranged and take part in class, understudies are more propelled, learn better, turn out to be better basic scholars, and have self-detailed increases in character (Rocca, 2010). Handelsman et al. (2005) found that as understudy commitment expands so do grades. This more profound handling has likewise been appeared to be prescient of expanded self-detailed learning and understudy commitment by and large appears to be prescient of test scores and in addition self-detailed learning (Gurung et al., 2012). Günüç and Kuzu (2014) found student engagement positively and significantly related with academic outcome. that Based on this discussion, hypothesis is as follows

H.3 Student engagement is positively related to academic outcomes.

The mediating effect of Job satisfaction

In above literature, it is stated that variable namely ASE, significantly affect student engagement and academic outcomes. It is also stated that student engagement significantly affects academic outcomes. So we suppose that job satisfaction plays mediating role in hypothesis 4 .

H.4 Through the mediating effect of Student engagement, ASE positively effect on academic outcomes.

\section{Research Method}

This research studied the relationship between ASE, student engagement and academic outcomes. Fig. 1 shows that ASE is an independent, student engagement mediator and academic outcome is a dependent variable. The data was collected through 3 sections, ASE, student engagement, and basic demographic data. The survey used the five-point lickert scale. The 33-item scale (CASES) in the ASE section (e.g., "Help is available from my organization when I have a problem.") is based on (Owen \& Froman, 1988). The 23-item scale (SCEQ) in the student engagement section (e.g., "I make sure to study on a regular basis") was adopted from (Handelsman et al., 2005). Descriptive, reliability analysis and also mediation analysis was used in this study. 
INTERNATIONAL JOURNAL OF ACADEMIC RESEARCH IN BUSINESS AND SOCIAL SCIENCES

Vol. 8, No. 11, Nov, 2018, E-ISSN: 2222-6990 @ 2018 HRMARS

Table No. 1 Characteristics of respondents

\begin{tabular}{llll} 
Variables & Sample $(\mathbf{N}=\mathbf{1 6 9})$ & Percent (\%) & Cumulative \\
\hline $\begin{array}{l}\text { Gender } \\
\text { Male }\end{array}$ & 101 & 59.7 & 59.7 \\
$\quad$ Female & 68 & 41.3 & 100 \\
$\begin{array}{l}\text { Department } \\
\text { ART \& SCl }\end{array}$ & 49 & 29 & 29 \\
$\quad$ Business & 101 & 59.76 & 88.7 \\
$\quad$ Communication & 20 & 11.8 & 100 \\
Year & & & \\
$\quad$ First year & 54 & 31.9 & 31.9 \\
$\quad$ Senior & 40 & 23.6 & 55.5 \\
$\quad$ Junior & 75 & 44.5 & 100
\end{tabular}

\section{Procedure}

The 182 students filled in the demographic data, completed the, College Academic Self-Efficacy Scale (CASES), Student Course Engagement Questionnaire (SCEQ) and self-reported their current GPAs. A list of GPAs was also taken form university administration for the cross check. The procedure took place in the spring term of 2018 during class-time and the students were asked to respond individually. They were given to realize that their answers would stay classified. Ethical measures were taken to protect the rights of the participants throughout the study.

\section{Research findings}

Respondents' Profile

A total of 182 questionnaires were filled, 13 were eliminated due to some problems, so only 169 questionnaires were collected with the response rate of $92 \%$. Table 1 shows that most respondents were male: 100 participants (75.4 \%). Educational levels mostly were senior 108 (52.7\%).

4.2) Descriptive analysis

The descriptive analysis is shown in table.2. The ASE was positively correlated with student engagement and academic outcomes. Positive correlation was there between student engagement and academic outcome (grade). Reliability test was performed for checking internal consistency. According to (Sekaran, 1992) for checking multiple scales reliability alpha is the most mainstream measure. Alpha was more .70 indicated internal consistency (ASE $=.81$; student engagement $=.85$ ) (Nunnally, 1978). 
INTERNATIONAL JOURNAL OF ACADEMIC RESEARCH IN BUSINESS AND SOCIAL SCIENCES

Vol. 8, No. 11, Nov, 2018, E-ISSN: 2222-6990 @ 2018 HRMARS

Table: 2

Descriptive

analyses.

$\mathrm{N}=169 \quad$ Mean (S.D.) Cronbach's $\quad$ Correlation

1. Grade

$2.1085(.59)$

1

2. ASE

$1.6028(.49)$

3. Student engagement $2.3665(.67)$

.81

.52

$.28 \quad .34 \quad 1$

\section{Regression Analysis}

For examining the proposed relationship, a series of multiple regression analysis were performed. Baron and Kenny (1986) testing approach was utilized to check whether student engagement was a mediating variable. The methodology for regression examinations are as per the following: (1) check the relation between (regression) dependent variable on the independent variable (Path C); (2) check the relation between (regression) intervening variable on the independent variable (Path A); and (3) regressing the dependent variables on the independent variable (Path $C^{\prime}$ ) and mediator (Path $B$ ) (Baron and Kenny, 1986).

Therefore, the study verified each hypothesis via a three-step approach: first 2 steps must be significant (1) the path regression between ASE and student engagement; (2) regressing academic outcome on ASE; (3) the path regression of student engagement on academic outcome. If ASE shows significance on student engagement, student engagement shows significance on academic outcomes, and ASE shows no significance on academic outcomes, then student engagement is likely a mediator. If ASE still shows significance on student engagement, but the coefficients are condensed, it indicates that there is a partial mediator. In other words, ASE influence academic outcome directly and indirectly through student engagement.

Table shows the regression equations which were conducted in this study. Hypothesis 1 was tested with the help of equation 1 which proposes that b1 should be significant and positive. And other hypotheses were tested by other three equations. Hypotheses 2 and 3 propose that b1 and b2 should be significant and positive in Eq. (2). In Eq. (3), Hypotheses 4 and suggest that b1 and b2 should be

\section{Table 3}

\section{Multiple regression Equations}

$$
\begin{aligned}
& S E=\beta O+\beta 1 A S E+e \\
& A O=\beta O+\beta 1 A S E+e \\
& A O=\beta O+\beta 1 S E+e \\
& A O=\beta O+\beta 1 A S E+\beta 2 S E+e
\end{aligned}
$$

NOTE: ASE: academic self-efficacy; SE: student engagement; AO: academic outcome; $\beta$ : regression coefficient; e: error term 
statistically significant and negative. Finally, in the last equation, Hypothesis 4 proposes that b3 must be significant. It was also expected that b1 and b2 would be weaker in the last equation while b3 would be significant.

Results are presented in table. Equation 1 shows that ASE positively and significantly affected student engagement ( $A S E \rightarrow$ SE: 0.52, $p<0.001, R=.24$ ); thus validating hypothesis 1 . Equation 2 confirms that ASE significantly and positively related to academic outcomes (ASE $\rightarrow$ AO: $0.34, p<0.001$ ) therefore hypothesis 2 was supported. In equation 3 , it is shown that student engagement.

\section{Table 4:}

\section{Regression Estimates of Equations}

Independent variable Dependent variable Unstandardized

Eq. (1) ASE

S.E

R2 (adjusted R2) .25 (.24)

Eq. (2) ASE

$\mathrm{AO}$ R2 (adjusted R2) .58 (.58)

Eq. (3)

SE $\quad A O$

R2 (adjusted R2) 59 (.59)

Eq. (4) ASE

$\mathrm{AO}$

AO

R2 (adjusted R2) .72 (.71)
.61

.401

.52

.34

.420

.28

$7.87^{* *}$

.301

.369
.144

.191 value Standardized

had significant and positive effect on academic outcome (SE $\rightarrow$ AO: .28, $p<0.001$ ), validating hypothesis 3. The equation 1 indicated that ASE had relatively high value and was significant. But in Eq.4 effect of ASE on academic outcome was relatively low but still significant. It means student engagement was not a full mediator in this study, perhaps the coefficients were condensed meaning student engagement was partial mediator. Fig. 2 shows the research findings, and Table 4 summarizes the hypothesis results.

\section{Discussion}

5.1) The relationship among Academic self-efficacy, student engagement and Academic performance ASE positively affected student engagement and academic outcome. Once the students get ASE they are likely to be more engage with their study. The findings of study echoed previous research (Papa, 2015), that ASE positively and significantly affect student engagement. A change in student engagement can lead to change in academic outcome. ASE was positively related with academic outcomes and it have been proved in previous studies too. Afari at el, (2012), found that ASE was related with academic outcomes. When students have high ASE then academic outcomes tend to be greater.

\subsection{2) The relationship between student engagement and Academic performance}

The findings of the study showed that student engagement positively affected academic outcomes. Once the students get engaged with the study they get more achievements in their academic career. 
INTERNATIONAL JOURNAL OF ACADEMIC RESEARCH IN BUSINESS AND SOCIAL SCIENCES

Vol. 8, No. 11, Nov, 2018, E-ISSN: 2222-6990 @ 2018 HRMARS

The findings of study showed result as previous research (Gurung et al., 2012; Rocca, 2010), that student engagement affects academic outcomes.

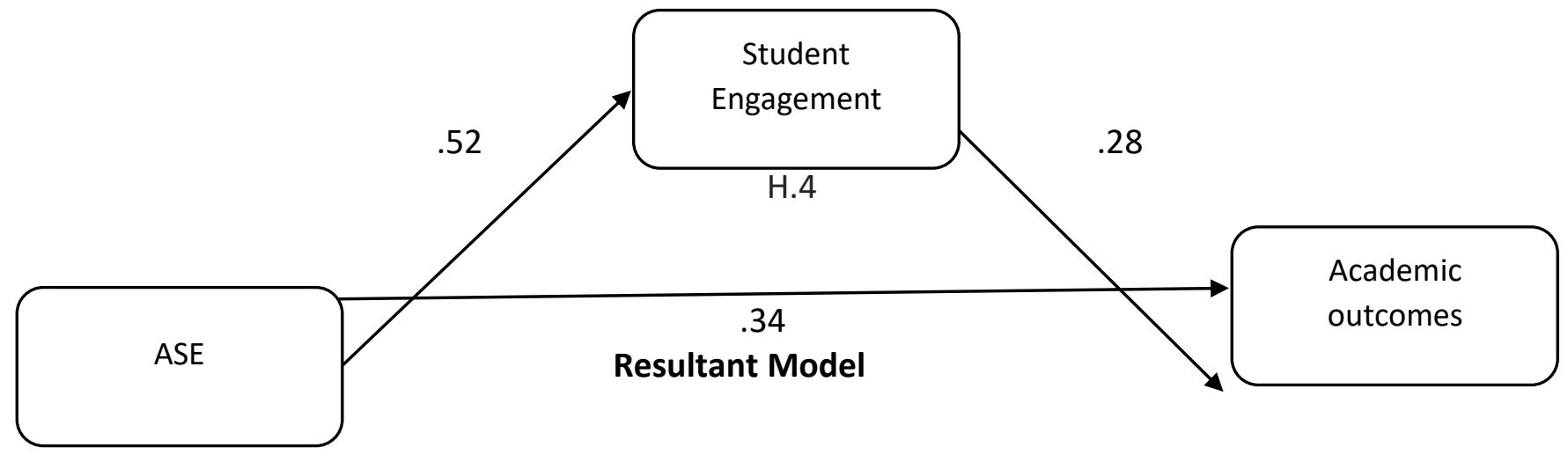

The mediating effects of student engagement

In this study, it was shown that ASE influence academic outcome and students engagement. Student engagement also effects academic outcome positively and significantly so it plays a role of partial mediator between ASE and Academic outcome meaning that ASE influence academic outcomes directly as well as indirectly through student engagement. The result rebounded previous study, (Papa, 2015) proved ASE influence academic outcome directly as well as indirectly through student engagement.

\section{Conclusion and Suggestions}

\section{Conclusion and implication}

The study verified all variables ASE, student engagement and academic outcome as the research framework. Causal relationship was checked. It was concluded that ASE positively influenced student engagement and academic outcome, as did student engagement. Student engagement showed a partial mediation effect between ASE and academic outcome. The study proved that academic outcomes get increased with high level of ASE among students and ASE was the caused to enhance student engagement too.

The study proves ASE, student engagement and academic outcome all were related, and was supporting past research. This study proved existing studies so it helped to enhance generalizability and was addition in literature. So Practically teachers must think that ASE effects academic outcomes directly as well as indirectly through engagement. And even if teachers are able to engage their students, they are more likely to achieve positive academic outcomes.

\section{Research Limitations and Future Research Suggestions}

Data was collected from student of university, so this study only applies to university and cannot be extended. Male respondents were dominant in numbers in this study so question might raise on gender discrimination. Student engagement was seen as a whole and its sub parts were not discussed, so it limits our study. In future all the sub parts of engagement can be examined as mediator. Technique for sampling and even sample size can be changed in future can be changed because sample size was not big enough. Mixed or multiple method can be used in future research 
INTERNATIONAL JOURNAL OF ACADEMIC RESEARCH IN BUSINESS AND SOCIAL SCIENCES

Vol. 8, No. 11, Nov, 2018, E-ISSN: 2222-6990 @ 2018 HRMARS

for better results. In this study, ASE was used as independent variables, student engagement was mediator future researches may use other independent variables. SEM can be used in next studies.

\section{References}

Adeyemo, D. (2007). Moderating influence of emotional intelligence on the link between academic self-efficacy and achievement of university students. Psychology and developing societies, 19(2), 199-213.

Afari, E., Ward, G., \& Khine, M. S. (2012). Global self-esteem and self-efficacy correlates: Relation of academic achievement and self-esteem among Emirati students. International Education Studies, 5(2), 49.

Bandura, A. (1989). Human agency in social cognitive theory. American psychologist, 44(9), 1175.

Bandura, A. (2006). Adolescent development from an agentic perspective. Self-efficacy beliefs of adolescents, 5, 1-43.

Bandura, A., \& Wessels, S. (1997). Self-efficacy: W.H. Freeman \& Company.

Baron, R. M., \& Kenny, D. A. (1986). The moderator-mediator variable distinction in social psychological research: Conceptual, strategic, and statistical considerations. Journal of personality and social psychology, 51(6), 1173.

Bergin, D. A. (1992). Leisure activity, motivation, and academic achievement in high school students. Journal of Leisure Research, 24(3), 225-239.

Bjarnason, T. (2000). Grooming for success? The impact of adolescent society on early intergenerational social mobility. Journal of Family and Economic Issues, 21(4), 319-342.

Bresó, E., Schaufeli, W. B., \& Salanova, M. (2011). Can a self-efficacy-based intervention decrease burnout, increase engagement, and enhance performance? A quasi-experimental study. Higher Education, 61(4), 339-355.

Brown, S. D., \& Lent, R. W. (2006). Preparing adolescents to make career decisions: A social cognitive perspective. Adolescence and education, 5, 201-223.

Brown, S. D., Lent, R. W., \& Larkin, K. C. (1989). Self-efficacy as a moderator of scholastic aptitudeacademic performance relationships. Journal of Vocational Behavior, 35(1), 64-75.

Coutinho, S. A., \& Neuman, G. (2008). A model of metacognition, achievement goal orientation, learning style and self-efficacy. Learning environments research, 11(2), 131-151.

Daniels, L. M., Stupnisky, R. H., Pekrun, R., Haynes, T. L., Perry, R. P., \& Newall, N. E. (2009). A longitudinal analysis of achievement goals: From affective antecedents to emotional effects and achievement outcomes. Journal of Educational Psychology, 101(4), 948.

De Clercq, M., Galand, B., Dupont, S., \& Frenay, M. (2013). Achievement among first-year university students: an integrated and contextualised approach. European Journal of Psychology of Education, 28(3), 641-662.

Farooq, R. A. (1994). Education system in Pakistan: Issues and problems: Asia Society for PR.

Feldman, D. B., \& Kubota, M. (2015). Hope, self-efficacy, optimism, and academic achievement: Distinguishing constructs and levels of specificity in predicting college grade-point average. Learning and Individual Differences, 37, 210-216. 
INTERNATIONAL JOURNAL OF ACADEMIC RESEARCH IN BUSINESS AND SOCIAL SCIENCES Vol. 8, No. 11, Nov, 2018, E-ISSN: 2222-6990 @ 2018 HRMARS

Galyon, C. E., Blondin, C. A., Yaw, J. S., Nalls, M. L., \& Williams, R. L. (2012). The relationship of academic self-efficacy to class participation and exam performance. Social Psychology of Education, 15(2), 233-249.

Goel, A. (2004). Education and socio-economic perspectives of women development and empowerment: Deep and Deep Publications.

Günüç, S., \& Kuzu, A. (2014). Factors influencing student engagement and the role of technology in student engagement in higher education: campus-class-technology theory. Turkish Online Journal of Qualitative Inquiry, 5(4), 86-113.

Gurung, R., Daniel, D., \& Landrum, R. (2012). A multi-site study of learning: A focus on metacognition and study behaviors. Teaching of Psychology, 39, 170-175.

Handelsman, M. M., Briggs, W. L., Sullivan, N., \& Towler, A. (2005). A measure of college student course engagement. The Journal of Educational Research, 98(3), 184-192.

Harper, S. R., \& Quaye, S. J. (2009). Beyond sameness, with engagement and outcomes for all. Student engagement in higher education, 1-15.

Hsieh, P., Sullivan, J. R., \& Guerra, N. S. (2007). A closer look at college students: Self-efficacy and goal orientation. Journal of Advanced Academics, 18(3), 454-476.

Krause, K. L., \& Coates, H. (2008). Students' engagement in first-year university. Assessment \& Evaluation in Higher Education, 33(5), 493-505.

Kuh, G. D. (2001). Assessing what really matters to student learning inside the national survey of student engagement. Change: The Magazine of Higher Learning, 33(3), 10-17.

Kuh, G. D. (2009). What student affairs professionals need to know about student engagement. Journal of college student development, 50(6), 683-706.

Lillydahl, J. H. (1990). Academic achievement and part-time employment of high school students. The journal of economic education, 21(3), 307-316.

Lockhart, P. (2004). An investigation into the causes of student drop out behaviour. University of Glasgow,

Martha, K. (2009). Factors affecting academic performance of undergraduate students at Uganda Christian University. Unpub. Master of Arts in Educational Management Dissertation, Makerere University, Uganda.

Multon, K. D., Brown, S. D., \& Lent, R. W. (1991). Relation of self-efficacy beliefs to academic outcomes: A meta-analytic investigation. Journal of counseling psychology, 38(1), 30.

Nunnally, J. (1978). Psychometric methods. In: New York: McGraw-Hill.

Owen, S. V., \& Froman, R. D. (1988). Development of a College Academic Self-Efficacy Scale.

Papa, L. A. (2015). The impact of academic and teaching self-efficacy on student engagement and academic outcomes.

Rocca, K. A. (2010). Student participation in the college classroom: An extended multidisciplinary literature review. Communication education, 59(2), 185-213.

Sabir, F. (2009). GENDER and EDUCATION IN PAKISTAN-Rashida Qureshi and Jane FA Rarieya. Journal of Gender and Social Issues, 8(2).

Sekaran, U. (1992). Research Methods For Business, Canada. In: John Wiley ve Sons, Inc. 
Sheu, H.-B., Lent, R. W., Brown, S. D., Miller, M. J., Hennessy, K. D., \& Duffy, R. D. (2010). Testing the choice model of social cognitive career theory across Holland themes: A meta-analytic path analysis. Journal of Vocational Behavior, 76(2), 252-264.

Weaver, R. R., \& Qi, J. (2005). Classroom organization and participation: College students' perceptions. The Journal of Higher Education, 76(5), 570-601.

Wood, R. E., \& Locke, E. A. (1987). The relation of self-efficacy and grade goals to academic performance. Educational and psychological measurement, 47(4), 1013-1024.

Yıldırım, i., \& Ergene, T. (2003). Social support, submissive acts, and test anxiety as predictors of academic achievement among high school students. Hacettepe Üniversitesi Eğitim Fakültesi Dergisi, 25, 224-234.

\section{Corresponding Author:}

Ali Hasan

University of Narowal

Jilani Colony Street 5, Narowal, Punjab, Pakistan

Email: ahasan.hasan4@gmail.com 